\title{
Delineation of groundwater potential zones in rocky aquifers in the mountainous area of central Nepal
}

\author{
*Dinesh Pathak ${ }^{1}$ and Surendra Raj Shrestha ${ }^{2}$ \\ ${ }^{1}$ Central Department of Geology, Geodisaster Research Center, Tribhuvan University, Kathmandu, Nepal \\ ${ }^{2}$ Groundwater Resources Development Board, Babarmahal, Kathmandu, Nepal
}

(*Email:dpathaktu@gmail.com)

\begin{abstract}
Groundwater is the lifeline for the people residing in the mountainous regions of Nepal as they are dependent in this natural resource for drinking and other domestic purposes. The springs and seepages are reported to be drying in many places in Nepalese mountains in the recent time. Such problem is expected to be much more severe in view of climate change condition in the future. In this regard, it is important to establish a methodology to explore groundwater in the mountainous terrain for better planning. In order to delineate groundwater potential zones of rocky aquifers in the mountainous terrain, study has been carried out in Melamchi watershed, lying in the Sindhupalchowk district, Nepal. Various thematic layers have been prepared in GIS and the satellite imageries have been used to extract relevant information. Ranks and weights have been assigned to each thematic layer and its classes, respectively. The rasterized layers have been combined and classified and the resulting map is crossed with the existing springs. It is found that the moderate and high potential classes of the groundwater potential map are represented by the existing springs. This method is expected to be useful at the preliminary watershed level study of groundwater potential in the mountainous terrain of central Nepal.
\end{abstract}

Keywords: Rocky aquifers, groundwater scarcity, groundwater potential, lineament density, central Nepal.

Paper Received: 11 August 2015

Paper Accepted: 31 March 2016

\section{INTRODUCTION}

The importance of groundwater in mountainous area cannot be undermined since people residing in this area are dependent in this natural resource for the drinking and other domestic purposes. It has been reported in many places of the mountainous areas that the trend of springs and seepages which are principally fed by the groundwater has been drying in the recent time and few villages have been displaced due to water shortage. Such problem is expected to be much more severe in view of climate change condition in the future. In this regards, it is important to establish a methodology to explore groundwater in the mountainous terrain for better planning to avoid water deficiency problem in these areas in future. In order to delineate groundwater potential zones in the mountainous terrain, remote sensing and Geographic Information System (GIS) techniques are widely used.

Groundwater is said to be vitally important for drinking, irrigation, and domestic use. It is a form of water occupying the voids within a geological stratum. Water bearing formations of the earth's crust act as conduits for transmission and as reservoirs for storing water. The groundwater occurrence in a geological formation and the scope for its exploitation primarily depends on the formation porosity. High relief and steep slopes impart higher runoff, while topographical depressions increase infiltration. An area of high drainage density also increases surface runoff compared to a low drainage density area. Surface water bodies like rivers, ponds, etc., can act as recharge zones, enhancing the groundwater potential in the neighbourhood (Karanth 1987, Hrkal 1992 and 2001, Sujatha and Rajeswara Reddy 2003, Rai et al. 2005, Subramani et al. 2005, Mathes and Rasmusse 2006, El-Hames et al. 2011, Rekha et al. 2011, Anithamary et al. 2012, Magesh et al. 2012, Venkatramanan et al. 2012).

Hence, identification and quantization of these features are important for generating a groundwater potential model of an study area. The different hydrogeological themes can be used to identify the groundwater potential zone. Chi and Lee (1994), Krishnamurthy et al. (1996) and Ramkumar et al. (2011) successfully used remote sensing and Geographic Information System (GIS) in a diverse geological setup for the demarcation of groundwater potential zones in Kochang, Korea, and Marudaiyar river basin, Tamilnadu, India, respectively. Analysis of remotely sensed data along with the topographical maps and collateral information with necessary ground truth verifications help in generating the baseline information for groundwater targeting. Sankar (2002), Bagyaraj et al. (2013), Lokesha et al. (2005), and Rai et al. (2005) found that identification of groundwater occurrence location using remote sensing data is based on indirect analysis of directly observable terrain features like geological structures, geomorphology, and their hydrologic characteristics. Bahuguna et al. (2003) found that lineaments play significant role in groundwater exploration particularly in hard rock terrain. Srinivasa and Jugran (2003) have applied GIS for processing and interpretation of groundwater quality data. Mohammed et al. (2003) have carried out hydrogeomorphological mapping using remote sensing techniques for water resource management around paleochannels

The main objective of the present study was to establish methodology to delineate groundwater potential zones in 
the mountainous terrain with the help of remote sensing and Geographic Information System (GIS) techniques. Melamchi watershed in central Nepal has been considered for the present study covering both the Higher Himalaya and lesser Himalaya.

\section{STUDY AREA}

The Melamchi watershed lies in central Nepal and has approximate area of $389 \mathrm{~km}^{2}$ that consists of 14 village development committees (Fig. 1). Some of the VDC, partly falls within this watershed extending also to the adjacent watershed. Most of the settlements are distributed only at the southern halves of the study area as the High Himal area lies in the northern part.

\section{MATERIALS AND METHODS}

The data sets used in this study ware the digital topographic map of the Department of Survey, satellite imageries covering the study area, geological map of the area, rainfall data, and Census data followed by primary data collection from the field.

Satellite image was primarily used for the extraction of lineament in the study area and updating the drainage map. Different thematic layers were prepared, which plays vital role in defining the groundwater potential in the mountainous area (Fig. 2).

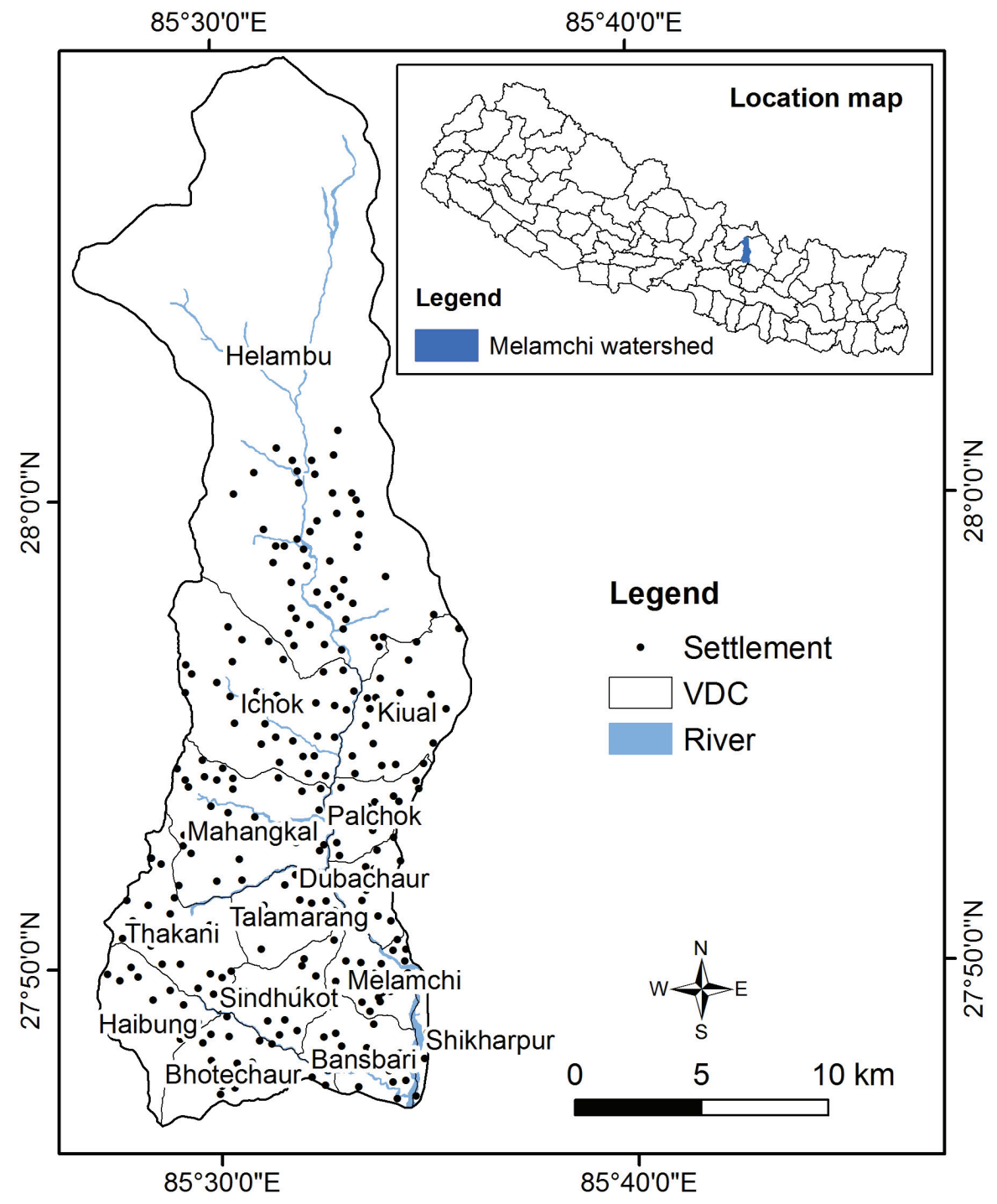

Fig. 1: Location map of Melamchi watershed with VDCs and settlements. 


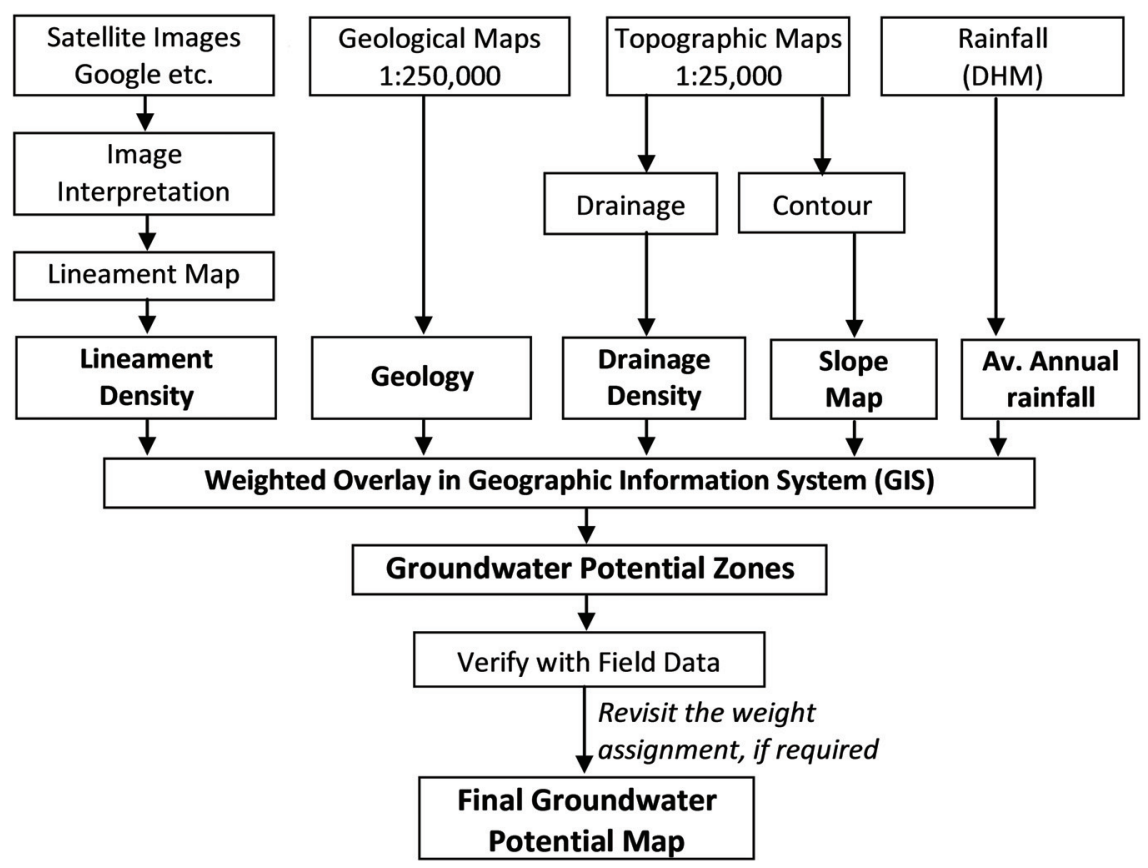

Fig. 2: Methodology adopted for delineating groundwater potential zones.

The thematic layers considered in the present study are lineament density, geology, drainage density, slope, landuse/ landcover, and rainfall. Ranks were assigned to these thematic layers and weights for classes of each layer. After rasterization, the layers were integrated to obtain the final output, which was further classified to get the groundwater potential map of the study area.

\section{RESULTS AND DISCUSSION}

\section{Geology}

The geological map of the Melamchi watershed is prepared from the hard copy geological map published by Department of Mines and Geology (DMG 1984). The watershed is dominantly comprises of Himal Group of rocks consisting of gneisses, granites with schist and carbonate rocks (Fig. 3). The southern part is consisting of quartzites and schists which are thrusted and faulted.

\section{Digital elevation model and elevation classes}

Digital Elevation Model (DEM) has been prepared from the contour map available on the digital topographic map of Department of Survey. This model has been used to obtain various elevation classes within the watershed (Fig. 4). The northern part is having high elevation than the southern part. The Melamchi river valley is represented by low elevation.

The watershed is classified into five different classes, in which the elevation ranging from 1500-2500 m occupies maximum area of the watershed followed by the elevation less than $1500 \mathrm{~m}$. The highest elevation area $(>4500 \mathrm{~m})$ is least within the watershed.

\section{Slope map}

Slope map has been prepared from the DEM. It is observed that the slope in Melamchi watershed ranges from flat around the river valley (terraces) to as steeper as 74 degree that mostly lie in the northern part of the watershed (Fig. 5). The maximum watershed area is covered by the 20-40 degree slopes. The area with slope less than 20 degree occupies around $20 \%$ of the watershed area.

\section{Lineament and lineament density}

Lineaments represent any linear geological structure that is resulted due to mechanical deformation on the rocks. It could be faults, thrusts, fold axes or joints. These are important features for the occurrence and movement of groundwater through the hard rocks.

Lineament map was prepared from the information available on the geological map and further updated from the satellite image (Fig. 6). The joints and other linear structures can be identified through the interpretation of the satellite imageries and aerial photographs (Pathak 2016). The high resolution satellite image used in the present study was quite helpful to identify regional as well as local scale lineaments.

The multispectral images of $10 \mathrm{~m}$ resolution as well as that of the high resolution image from Google Earth have been utilized for the lineament extraction purpose. The lineament and lineament density map for Melamchi watershed is presented in Fig. 7.

The lineament density map shows that the moderate to high lineament density area falls in the southern and central 


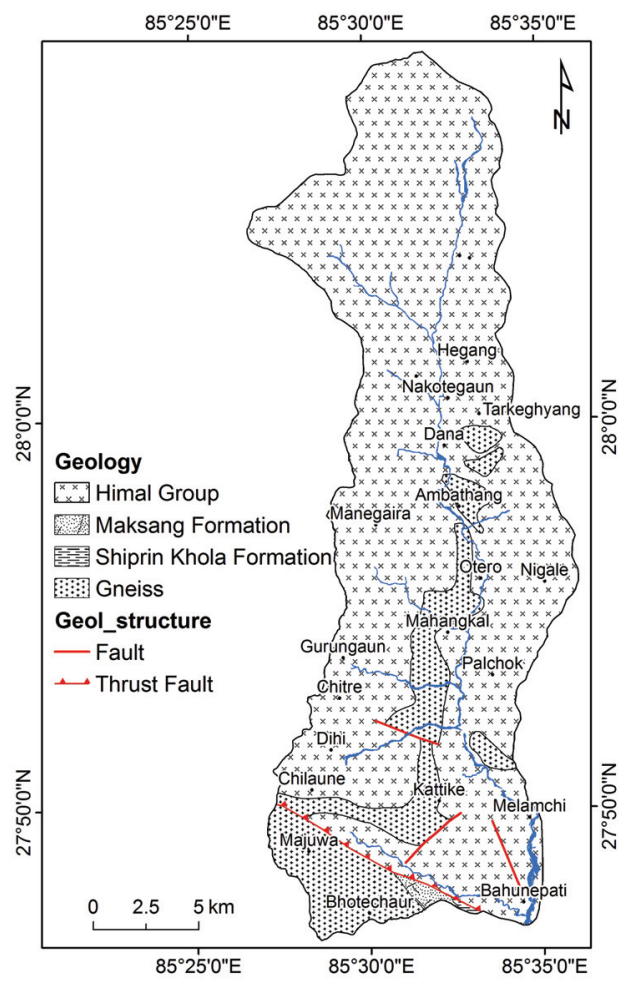

Fig. 3: Geological Map of the Melamchi watershed (DMG 1984).

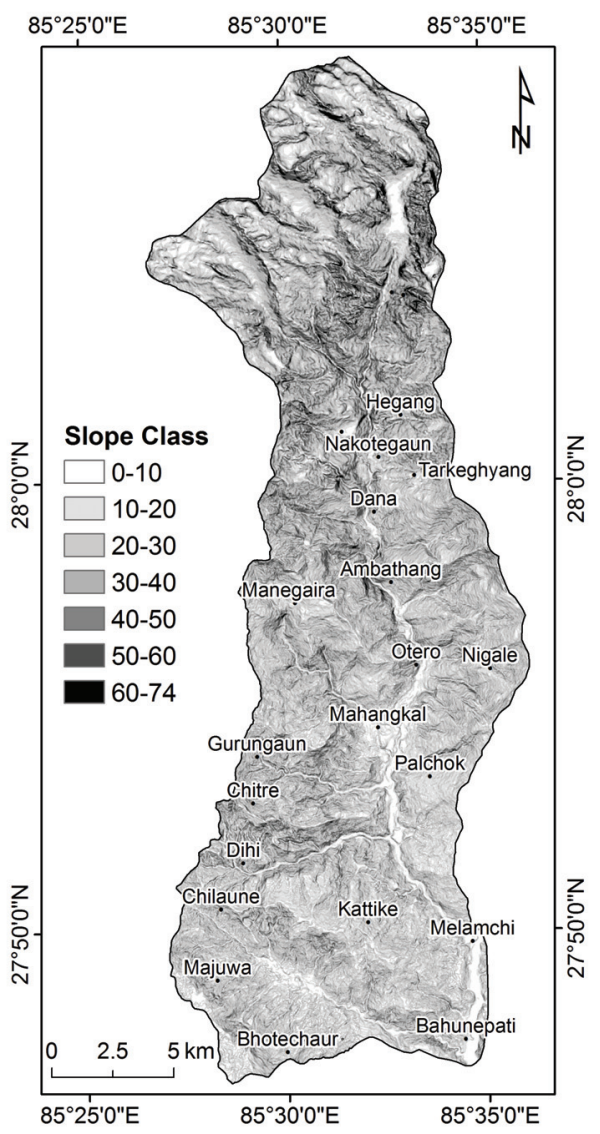

Fig. 5: Slope Map of the Melamchi watershed.

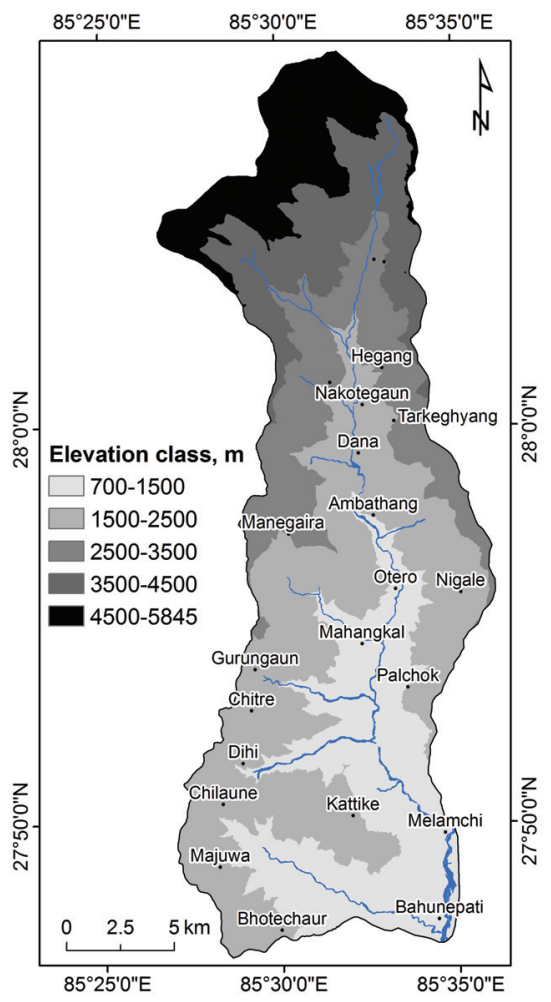

Fig. 4: Elevation classes in the Melamchi watershed.

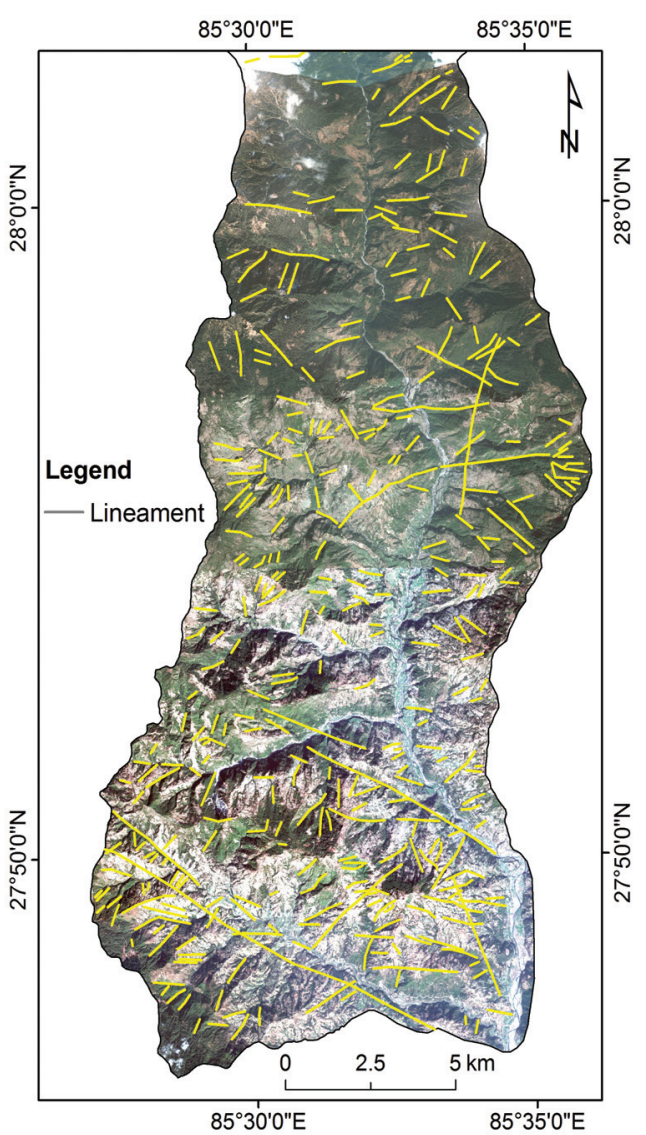

Fig. 6: Lineament extraction from the satellite image. 


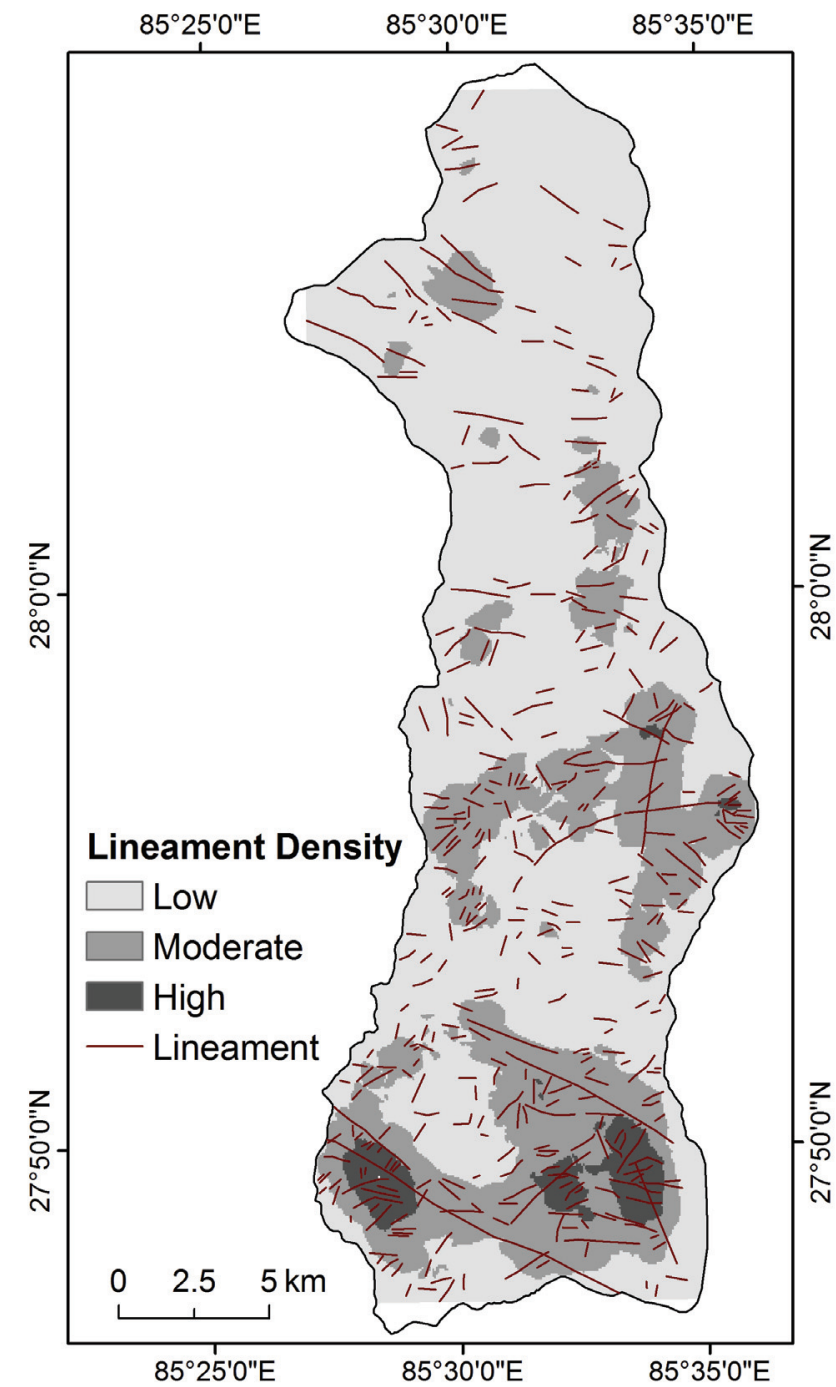

Fig. 7: Lineament density map of the watershed.

part of the watershed. The higher density is expected to significantly contribute for the availability of groundwater in hard rock aquifer.

\section{Drainage and drainage density}

The drainage system, which develops in an area, is strictly dependent on the slope, the nature and attitude of bedrock and on the regional and local fracture pattern. Drainage, which is easily visible on remote sensing imagery, therefore reflects to varying degrees the lithology and structure of a given area and can be of great value for groundwater resources evaluation.

The drainage network within the watershed was extracted from the digital topographic map of the Department of Survey. The map was further updated from the satellite imageries. However, it was not much helpful for the northernmost part of the study area as it is mostly covered by snow or dense cloud.

A drainage density map of the Melamchi watershed has been prepared (Fig. 8). The map shows that most of the study area is covered by moderate drainage density while the areas

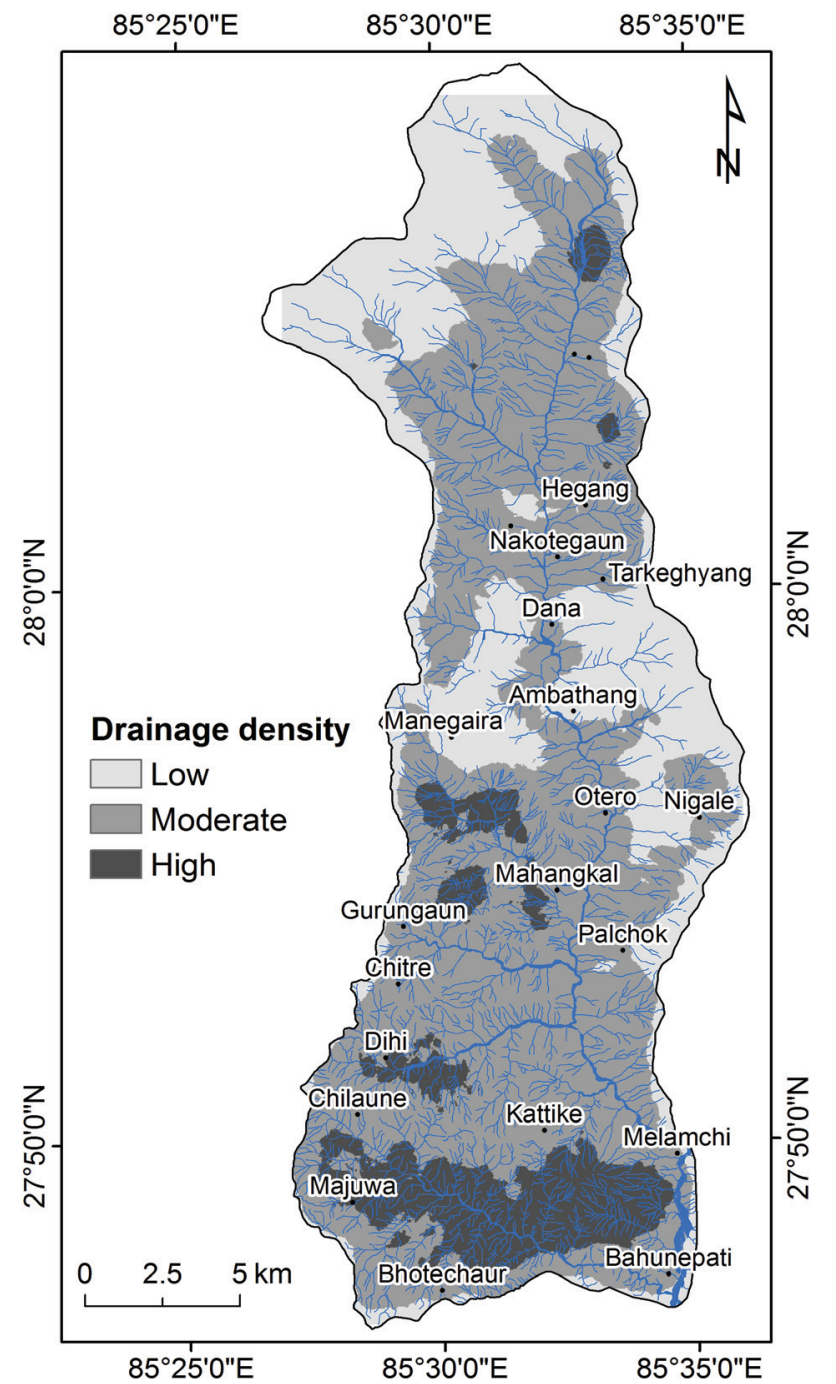

Fig. 8: Drainage density $\left(\mathrm{m} / \mathrm{km}^{2}\right)$ map of the Melamchi watershed.

with high and low drainage density cover comparatively less area within the watershed. The high drainage density refers to the increased overland flow of water thereby reducing the subsurface percolation while the low drainage density provides better condition for improved infiltration, therefore, is more desirable in delineating the groundwater potential zone.

\section{Land use/Land cover}

Land use/Land cover is another important parameter from the groundwater potential perspective. This map is prepared from the digital topographic map produced by the Department of Survey (Fig. 9). Five land use classes have been identified in the Melamchi watershed, namely cultivation (agriculture), forest, bush, grass and barren land. The maximum watershed area is covered by the agriculture land followed by barren land, bush and forest area. The grass land and water body occupies very negligible areas.

The cultivated land and area occupied by the water bodies are assumed to provide better opportunity for the groundwater 


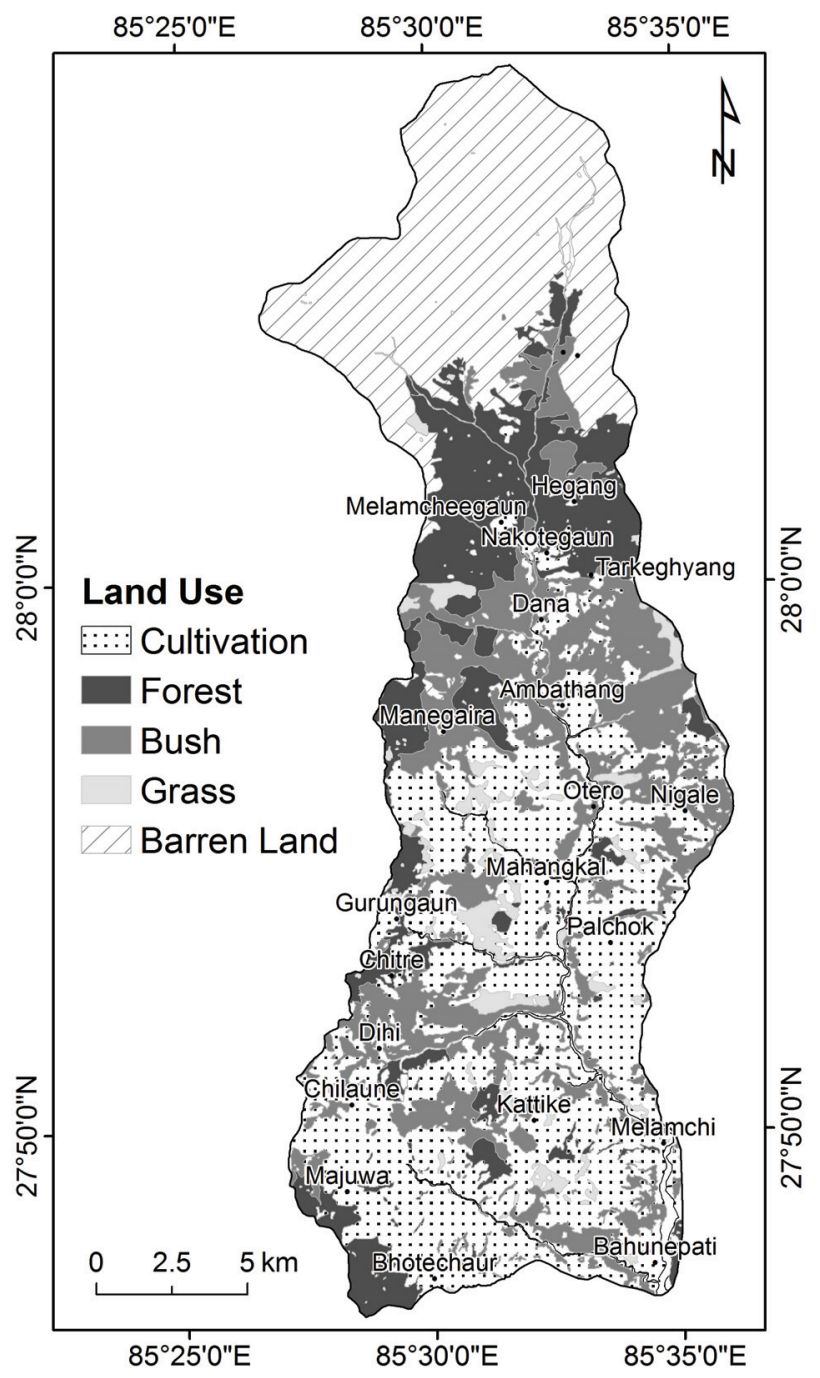

Fig. 9: Land use map of the watershed.

percolation. Likewise, the forest, grass and bush land acts as moderate potential due to water percolation through the loose soil due to root penetration on the soil. Similarly, the barren land is less suitable for the groundwater infiltration as these are lacking of vegetation, fall on steep slope and rocky areas and contributes more for overland flow.

\section{Physiography and precipitation}

Physiographically, the Melamchi watershed can be divided into three major zones, namely Middle mountain, High mountain and High himalaya from south to north (Fig. 10). There are number of meteorological stations falling within each zone. However, data is not available for significant period from all these stations. The average annual precipitation has been obtained from the long term measurement made at various stations falling within each physiographic region. The data are obtained for about 30 years period, which is normally used to observe the climatic variation within the region.

Since the precipitation distribution is principally governed by the physiography, one value can be assigned for a particular physiographic zone that is narrowly distributed

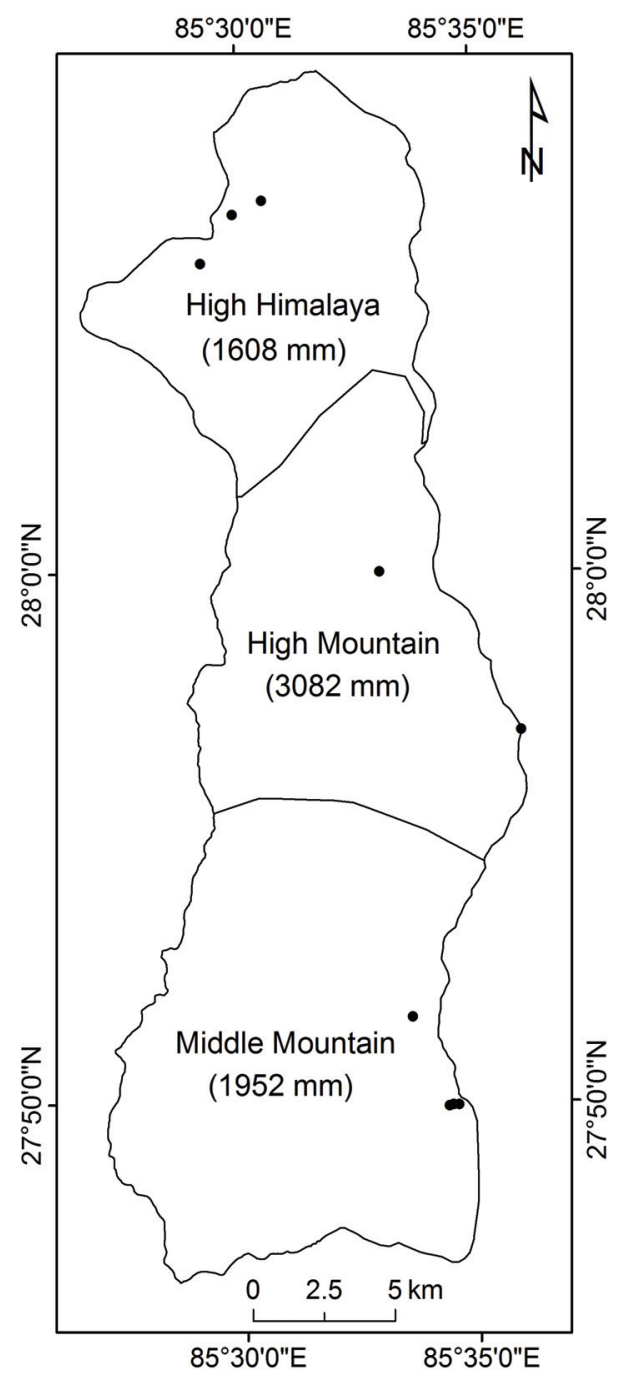

Fig. 10: Physiographic zone with meteorological stations and precipitation in each physiographic zone.

within the watershed. The Middle mountain region occupies the maximum area of the watershed followed by High mountain and High himalaya. The variation in average annual precipitation obtained for longer period of time shows that the High mountain region receives more precipitation while the High himalayan zone receives least within the watershed.

\section{Rank and weight assignment to thematic layers}

The total rank value is defined to be 100 , which is distributed to different thematic layers as per the importance to occurrence of groundwater. Similarly, the weightage for each classes ranges from 1 to 3 (Table 1). The GIS based analysis was carried out with this conceptual framework, which is established based on the terrain condition, field condition as observed during the field investigation as well as general characteristics of the geological condition within the watershed.

Maximum score has been given to the thematic layers of lineament density and slope. These two parameters are considered to be vital for the groundwater occurrence in 
fractured rock aquifers. The higher density of lineament provides suitable condition to store and transmit the groundwater. The higher lineament density also creates possibility for the interconnected fractures thereby facilitating the groundwater flow. In absence of the lineament, there is very poor chances of occurrence and movement of the groundwater in hard rock.

Likewise, slope is another important parameter for the occurrence and movement of groundwater. Gentle slope is generally favourable for groundwater storage while steeper slope drains water faster therefore considered as poor fractured aquifer. In addition, there is less possibility of water infiltrating into the ground at steeper groundwater surface, which is favourable for more overland flow.

Precipitation has control on the availability of groundwater. Higher amount of precipitation is favourable for significant groundwater recharge thereby increasing the possibility for better groundwater occurrence. Generally, lithological map is considered better to utilize in the analysis leading to identification of groundwater potential zone. However, in present case, there is lack of lithological map and hence different geological formations are used. This give rise to more generalization and hence lower rank value is given for this thematic layer.

Table 1: Rank and weightages assigned to different thematic layers.

\begin{tabular}{|c|c|c|c|c|}
\hline S. N. & Parameters & Classes & Rank & Weightage \\
\hline \multirow{3}{*}{1} & \multirow{3}{*}{ Geology } & Himal Group & \multirow{3}{*}{10} & 3 \\
\hline & & Gneiss & & 2 \\
\hline & & Maksang and Siprin Khola Fm. & & 1 \\
\hline \multirow{3}{*}{2} & \multirow{3}{*}{ Drainage Density } & Low & \multirow{3}{*}{5} & 3 \\
\hline & & Moderate & & 2 \\
\hline & & High & & 1 \\
\hline \multirow{3}{*}{3} & \multirow{3}{*}{ Lineament Density } & Low & \multirow{3}{*}{30} & 1 \\
\hline & & Moderate & & 2 \\
\hline & & High & & 3 \\
\hline \multirow{3}{*}{4} & \multirow{3}{*}{ Slope } & Gentle $(0-10)$ & \multirow{3}{*}{30} & 3 \\
\hline & & Moderate (10-35) & & 2 \\
\hline & & Steep $(>35)$ & & 1 \\
\hline \multirow{6}{*}{5} & \multirow{6}{*}{ Land Use } & Cultivation & \multirow{6}{*}{10} & 3 \\
\hline & & Forest & & 2 \\
\hline & & Bush & & 2 \\
\hline & & Grass & & 2 \\
\hline & & Barren Land & & 1 \\
\hline & & Water body & & 3 \\
\hline \multirow{3}{*}{6} & \multirow{3}{*}{ Precipitation } & Low & \multirow{3}{*}{15} & 1 \\
\hline & & Moderate & & 2 \\
\hline & & High & & 3 \\
\hline & & Total & 100 & \\
\hline
\end{tabular}

As mentioned earlier, land use is an important parameter for the groundwater potentiality in an area. The agriculture land is normally ploughed and soil has become porous permitting the recharge through fractures underlying the soil. Likewise, existing water bodies (like pond, lake, river etc.) are other sources for significant groundwater recharge. However, the area covered by vegetation also supports for groundwater recharge obstructing the overland flow and allowing water percolating through root zones. However, the barren land are least supportive for groundwater recharge as the bare ground surface permits more for overland flow due to low permeability of the soil.

Drainage density suggests the permeability of the ground surface. The higher value means relatively impermeable ground surface with limited infiltration of water. It is normally observed either on massive rocks or impermeable soil. However, groundwater recharge through steeply sloping mountainous rivers and tributaries is less significant in comparison to other parameters considered. Therefore, the least rank value is given for this thematic layer.

\section{Groundwater potential map}

The groundwater potential of the Melamchi watershed has been prepared through overlay analysis in GIS that utilizes the ranks and weight for each thematic parametric layer and respective classes as presented in the above table (Table 1). Thus obtained groundwater potential map is presented in Fig. 11 below.

The map shows that the low groundwater potential zone occupies around $51 \%$ of the watershed while moderate area occupies around $44 \%$ and high potential area is only around $5 \%$ of the watershed. The moderate to high groundwater potential areas are mostly distributed in the southern, central and northwestern part of the watershed. The field investigation also revealed that most of the existing springs fall within moderate to high groundwater potential zone, suggesting that the obtained model can be considered as the preliminary estimation of the groundwater occurrence in the mountainous region. 


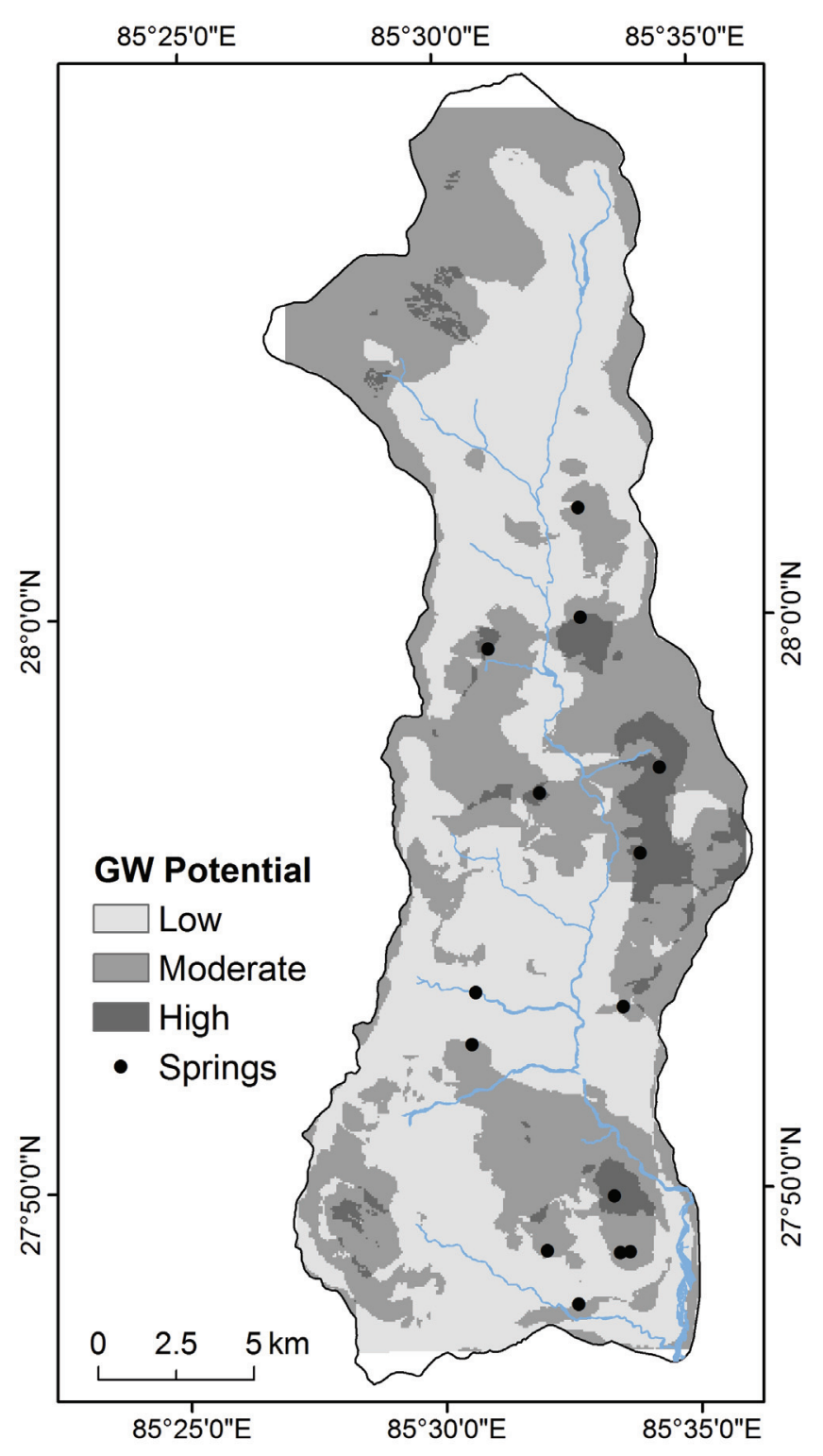

Fig. 11: Groundwater potential map of the watershed.

\section{CONCLUSIONS AND RECOMMENDATIONS}

Different informations like digital topographic maps, hard copy geological maps as well as remote sensing imageries were primarily utilized to prepare groundwater potential map of the Melamchi watershed. The parameters considered for identifying the groundwater potential zone of geology slope, drainage density, land use, precipitation and lineament density were generated using the satellite imageries and toposheets of scale 1:25000 and integrated them in the GIS to identify the groundwater potential of the study area. Suitable weightage factors were assigned for each category of these parameters based on their capability to store and transmit ground-water. The groundwater potential map shows that moderate to high groundwater potential areas are mostly distributed in the southern, central and northwestern part of the watershed, which was better validated with respect to the existing springs in these areas. The method used in the present study can be replicated in other parts of the country, however, the rank and weight values should be revisited to better represent the watershed condition under study.

\section{ACKNOWLEDGEMENT}

This article is based on the study carried out as part of the pilot project of Ground Water Resources Development Board (GWRDB), Government of Nepal entitled "Study of Hard Rock Aquifers in Hill and Mountainous Area of Central Nepal". The authors are thankful to GWRDB for giving permission to publish the data of the report.

\section{REFERENCES}

Anithamary, I., Ramkumar, T., and Venkatramanan, S., 2012, Application of statistical analysis for the hydrogeochemistry of saline groundwater in Kodiakarai, Tamilnadu. Journal of Coastal Research, v. 28 (1A), pp. 89-98.

Bagyaraj, M., Ramkumar, T., Venkatramanan, S., and Gurugnanam B., 2013, Application of remote sensing and GIS analysis for identifying groundwater potential zone in parts of Kodaikanal Taluk, South India. Front. Earth Sci., v. 7(1), pp. 65-75.

Bahuguna, I. M., Nayak, S., Tamilarasan, V., and Moses, J., 2003, Groundwater prospective zones in basaltic terrain using remote sensing. J Indian Soc Remote Sens, v. 31(2), pp. 101-105

Chi, K. H., and Lee, B. J., 1994, Extracting potential groundwater area using remotely sensed data and GIS techniques. In: Proceedings of the Regional Seminar on Integrated Applications of Remote Sensing and GIS for Land and Water Resources Management, Bangkok. Bangkok: Economic and Social Commission for Asia and the Pacific, pp. 64-69.

DMG (Department of Mines and Geology), 1984, Geological Map of Central Nepal, Scale 1:250,000. Kathmandu, Nepal.

El-Hames, A. S., Al-Ahmadi, M, and Al-Amri, N., 2011, A GIS approach for the assessment of groundwater quality in Wadi Rabigh aquifer, Saudi Arabia, Environ. Earth Sci, v. 63(6), pp. 1319-1331.

Hrkal, Z., 1992, Acidification of groundwater in the Bohemian Massif. Nor Geol Unders Bull, v. 422(7), pp. 97-102.

Hrkal, Z., 2001, Vulnerability of groundwater to acid deposition, Jizerske Mountains, northern Czech Republic: construction and reliability of a GIS-based vulnerability map. Hydrogeol J, v. 9(4), pp 348-357.

Karanth, K. R., 1987, Ground Water Assessment Development and Management. New York: McGraw-Hill.

Krishnamurty, J., Venkatesa Kumar, N., Jayaraman, V., and Manivel, M., 1996, An approach to demarcate 
groundwater potential zones through remote sensing and a geographical information system. Int J Remote Sensing, v. 7, pp. 1867-1884.

Lokesha, N., Gopalakrishna, G. S., Honne Gowda, H., and Gupta, A. K., 2005, Delineation of groundwater potential zones in a hard rock terrain of Mysore district, Kamatak using IRS data and GIS techniques. Journal of Indian Soc. Remote Sens., v. 33(3), pp. 405-412.

Magesh, N. S., Chandrasekar, N., and Soundranayagam, J. P., 2012, Delineation of groundwater potential zones in Theni district, Tamil Nadu, using remote sensing, GIS and MIF Techniques. Geoscience Frontiers, v. 3(1), pp. 189-196.

Mathes, E. S., and Rasmussen, T. C., 2006, Combining multivariate statistical analysis with geographic information systems mapping: a tool for delineating groundwater contamination. Hydrogeol J, v. 14(8), pp. 1493-1507.

Mohammed, A., Balasubramanian, A., Kondoh, A., Rokhmatuloh, R., and Mustafa, A. J., 2003, Hydrogeomorphological mapping using remote sensing techniques for water resource management around palaeochannels, geoscience and remote sensing symposium, IGARSS-APOS; 03. In: Proceedings of the 2003 IEEE International, Toulouse, France.

Pathak, 2016, Knowledge based landslide susceptibility mapping in the Himalayas. Geoenvironmental Disasters, v. 3(8). doi: 10.1186/s40677-016-0042-0.

Rai, B., Tiwari, A., and Dubey, V. S., 2005, Identification of groundwater prospective zones by using remote sensing and geoelectrical methods in Jarla and Raniganj coalfields, Dhanbad district, Jharkhand state. J of Earth System Sciences, v. 114(5), pp. 515-522.

Ramkumar, T., Venkatramanan, S., Anithamary, I., and Syed Ibrahim, S. M., 2011, Evaluation of hydrogeochemical parameters and quality assessment of the groundwater in Kottur blocks, Tiruvarur district, Tamilnadu, India. Arab J Geosciences, doi: 10.1007/s12517-011-0327-2.

Rekha, V. B., Thomas, A. P., Suma, M., and Vijith, H., 2011, An integration of spatial information technology for groundwater potential and quality investigations in Koduvan Ár, sub-watershed of Meenachil River basin, Kerala, India. J Indian Soc Remote Sens, v. 39(1), pp. 63-71.

Sankar, K., 2002, Evaluation of groundwater potential zones using remote sensing data in upper Vaigai River basin, Tamil Nadu, India. J Indian Soc Remote Sens, v. 30(3), pp. 119-129.

Srinivasa, R. Y. and Jugran, K. D., 2003, Delineation of groundwater potential zones and zones of groundwater quality suitable for domestic purposes using remote sensing and GIS. Hydrol Sci J, v. 48(5), pp. 821-833.

Srivastava, V. K., Giri, D. N., and Bharadwaj, P., 2012, Study and mapping of ground water prospect using remote sensing, GIS and geoelectrical resistivity techniques - a case study of Dhanbad district, Jharkhand, India, J. Ind. Geophys. Union, v. 16(2), pp. 55-63.

Subramani, T., Elango, L., and Damodarasamy, S. R., 2005, Groundwater quality and its suitability for drinking and agricultural use in Chithar River basin, Tamil Nadu, India. Environ Geol, v. 47(8), pp. 1099-1110.

Sujatha, D., and Rajeswara Reddy, B., 2003, Quality characterization of groundwater in the south-eastern part of the Ranga Reddy district, Andhra Pradesh, India. J Environ Geology, v. 44(5), pp. 579-586.

Venkatramanan, S., Ramkumar, T., and Anithamary, I., 2012, A statistical approach on hydrogeochemistry of groundwater in Muthupet coastal region, Tamilnadu, India. Carpathian. Journal of Earth and Environmental Sciences, v. 7(1), pp. 47-54. 